\title{
Uncertainties in the global temperature change caused by carbon release from permafrost thawing
}

\author{
E. J. Burke ${ }^{1}$, I. P. Hartley ${ }^{2}$, and C. D. Jones ${ }^{1}$ \\ ${ }^{1}$ Met Office Hadley Centre, FitzRoy Road, Exeter, EX1 3PB, UK \\ ${ }^{2}$ Geography, College of Life and Environmental Sciences, University of Exeter, Rennes Drive, Exeter, EX4 4RJ, UK \\ Correspondence to: E. J. Burke (eleanor.burke@metoffice.gov.uk)
}

Received: 23 February 2012 - Published in The Cryosphere Discuss.: 5 April 2012

Revised: 16 July 2012 - Accepted: 24 August 2012 - Published: 27 September 2012

\begin{abstract}
Under climate change thawing permafrost will cause old carbon which is currently frozen and inert to become vulnerable to decomposition and release into the climate system. This paper develops a simple framework for estimating the impact of this permafrost carbon release on the global mean temperature (P-GMT). The analysis is based on simulations made with the Hadley Centre climate model (HadGEM2-ES) for a range of representative $\mathrm{CO}_{2}$ concentration pathways. Results using the high concentration pathway (RCP 8.5) suggest that by 2100 the annual methane $\left(\mathrm{CH}_{4}\right)$ emission rate is $2-59 \mathrm{Tg} \mathrm{CH}_{4} \mathrm{yr}^{-1}$ and $50-270 \mathrm{PgC}$ has been released as $\mathrm{CO}_{2}$ with an associated P-GMT of 0.08 $0.36^{\circ} \mathrm{C}$ (all 5th-95th percentile ranges). P-GMT is considerably lower - between 0.02 and $0.11^{\circ} \mathrm{C}$ - for the low concentration pathway (RCP2.6). The uncertainty in climate model scenario causes about $50 \%$ of the spread in P-GMT by the end of the 21 st century. The distribution of soil carbon, in particular how it varies with depth, contributes to about half of the remaining spread, with quality of soil carbon and decomposition processes contributing a further quarter each. These latter uncertainties could be reduced through additional observations. Over the next $20-30 \mathrm{yr}$, whilst scenario uncertainty is small, improving our knowledge of the quality of soil carbon will contribute significantly to reducing the spread in the, albeit relatively small, P-GMT.
\end{abstract}

\section{Introduction}

Permafrost soil - soil which is below $0^{\circ} \mathrm{C}$ for $2 \mathrm{yr}$ or more - underlies approximately a quarter of the exposed land surface of the Northern Hemisphere (Zhang et al., 1999). Recent observations show that permafrost has typically warmed by 0.5 to $2{ }^{\circ} \mathrm{C}$, depending on location (Solomon et al., 2007; Etzelmüller et al., 2011; Osterkamp, 2007). In addition, measurements suggest there is an observable deepening of the permafrost active layer (Shiklomanov et al., 2010; Frauenfeld et al., 2004; Wu and Zhang, 2010; Callaghan et al., 2010; Isaksen et al., 2007). Future climate change projections suggest a marked warming at northern high latitudes of between 2.8 and 7.8 degrees (A1B scenario) by the end of the century (Solomon et al., 2007), which will result in further degradation of permafrost.

Permafrost soils contain $\sim 1672 \mathrm{Pg}$ of carbon (Tarnocai et al., 2009), much of which is permanently frozen, relatively inert and not currently included within the global carbon cycle. Any degradation of permafrost will cause a proportion of this old permafrost organic carbon to become more vulnerable to decomposition and to subsequently release into the climate system. Additional carbon released into the atmosphere will have a positive feedback on the global climate - it will cause a further increase in greenhouse gases in the atmosphere and result in more warming (Schuur et al., 2008). Estimates of the amount of permafrost carbon release under increased global temperature have been made by extrapolating site specific observations. For example, on the basis of laboratory incubation experiments, Dutta et al. (2006) estimated a potential release of about $40 \mathrm{Pg} \mathrm{C}$ if $10 \%$ of the carbon frozen in deep soils in Siberia thawed to $5^{\circ} \mathrm{C}$. Gruber et al. (2004) suggested that $20 \%$ of the permafrost carbon could be released by the end of the century. Schuur et al. (2009), extrapolating from measurements made at a single site in Alaska, suggested $0.8-1.1 \mathrm{Pg} \mathrm{C} \mathrm{yr}^{-1}$ could be lost if permafrost thaws. Raupach and Canadell (2008) extended 
this analysis and estimated the additional temperature increase caused by this permafrost carbon release to be $0.7^{\circ} \mathrm{C}$ with a $\mathrm{CO}_{2}$ increment of $80 \mathrm{ppm}$ by the end of this century.

Schuur et al. (2008) identified four mechanisms that cause permafrost carbon to be released to the atmosphere: (a) active layer thickening, (b) talik formation, (c) thermokarst development, and (d) river and coastal erosion. Climate model projections of permafrost degradation can presently represent (a) and (b) but not (c) or (d). However, model projections of permafrost degradation over the 21 st century are highly uncertain, ranging from a 7 to $88 \%$ loss of permafrost area and a 40 to $100 \%$ increase in active layer thickness (Schaefer et al., 2011). These uncertainties depend on study region, future emissions scenario and model (Schaefer et al., 2011; Koven et al., 2011; Schneider von Deimling et al., 2012). Schaefer et al. (2011) used a land surface scheme, which includes a mechanism for soil carbon decomposition driven by surface weather from a global climate model run under the SRES A1B emissions scenario. They calculated that $110 \pm 40 \mathrm{Pg} \mathrm{C}$ could be released by 2100 . They assumed the soil carbon decomposition rate to be that measured by Dutta et al. (2006) for yedoma soils in northern Siberia (Schuur et al., 2008). In addition, they did not consider wetlands or any methane $\left(\mathrm{CH}_{4}\right)$ release. Koven et al. (2011) included a vertically discretised soil carbon module and $\mathrm{CH}_{4}$ emissions from wetlands and permafrost in their land surface scheme. They used surface weather data calculated under the SRES A2 emissions scenario and showed a cumulative release of $62 \pm 7 \mathrm{PgC}$ due to the partial decomposition of the old permafrost carbon pool over the 21 st century. Schneider von Deimling et al. (2012) used a simple permafrost module coupled with a simple carbon-cycle climate model, and showed that for the RCP8.5 high concentration pathway an extra 33$114 \mathrm{Pg} \mathrm{C}$ (68\% range) are released by 2100 , which leads to an additional warming of $0.04-0.23^{\circ} \mathrm{C}$. A mechanism for permafrost carbon decomposition and release needs to be appropriately included within a global earth system climate model in order to fully quantify the permafrost carbon feedback

This paper estimates the permafrost global temperature change (P-GMT) that might have been calculated by the Hadley Centre Climate model if permafrost had been included. It adopts the following simple approach:

1. Physical changes in the near-surface permafrost were quantified using the climate model simulations.

2. These changes were then combined with knowledge of the distribution of Arctic soil carbon to assess the amount of carbon in the thawed permafrost made vulnerable to decomposition.

3. Representative $\mathrm{CO}_{2}$ and $\mathrm{CH}_{4}$ production rates, $\mathrm{CH}_{4}$ oxidation rates, $\mathrm{CH}_{4}$ transport pathways, and knowledge of the Arctic land cover were used to construct a sim- ple model to estimate the proportion of this vulnerable carbon released to the atmosphere.

4. The impact on the global temperature of the released $\mathrm{CO}_{2}$ and $\mathrm{CH}_{4}$ was quantified using a simple climate energy balance model.

Since large ensembles can be generated relatively cheaply by this simple framework, we can adopt it as a tool to explore how our limited understanding of many of the relevant parameters/processes associated with permafrost carbon decomposition and release impacts the uncertainty in P-GMT. This will enable the parameters/processes where greater understanding will lead to a reduction in the uncertainty to be identified. It will also inform the development of appropriate schemes to quantify the permafrost climate feedback in global earth system models.

\section{Modelling approach}

\subsection{Physical changes in near-surface permafrost}

Output from the Hadley Centre Global climate model (HadGEM2-ES; Jones et al., 2011; Collins et al., 2011b) was used to estimate the active layer thickness and its change in a future climate for soil depths down to $3 \mathrm{~m}$. HadGEM2-ES is a coupled climate model with an atmospheric resolution of $1.875^{\circ} \times 1.25^{\circ}$ and 38 vertical levels, and an ocean resolution of $1^{\circ}$ (increasing to $1 / 3^{\circ}$ at the equator) and 40 vertical levels. HadGEM2-ES also represents interactive land and ocean carbon cycles and dynamic vegetation. In addition, it simulates the evolution of atmospheric composition and interactions with atmospheric aerosols. HadGEM2-ES was used to simulate the historical period (1860-2006) and 4 future scenarios forced by different Representative Concentration Pathways (RCPs - Jones et al., 2011).

HadGEM2-ES calculates soil temperatures using a discretised form of the heat diffusion equations with the soil thermal characteristics as realistic functions of the soil moisture content. It also includes the latent heat from water phase changes in the subsurface calculations. There are no explicit snow layers in the model, but the top soil layer is adapted to represent lying snow processes. HadGEM2-ES treats all soil as mineral soil and does not consider the thermal and hydrological properties of organic soil horizons and mosses, which are particularly important when simulating soil temperatures in northern high latitudes. This leads to a stronger than expected dependence of active layer on latitude (and climate) and smaller than expected dependence on soil type.

The zero degree isotherm was diagnosed from the HadGEM2-ES simulated soil temperatures by fitting a thermal profile through the midpoints of each soil layer. The thaw depth is then defined by the depth at which the profile crosses the $0^{\circ} \mathrm{C}$ boundary. The active layer thickness is the annual maximum of the thaw depth. HadGEM2-ES surface 
meteorology includes the modelled response of the atmosphere to the driving climate, and therefore the modelled impact of a changing climate on, for example, snow cover, land cover, vegetation and any associated feedbacks are taken into account.

This paper only considers the top $3 \mathrm{~m}$ of the soil, and any soil organic matter deeper in the profile is assumed to remain inert over the timescales assessed. The land surface component of HadGEM2-ES has 4 soil layers $(0-10 \mathrm{~cm}, 10-35 \mathrm{~cm}$, $35-100 \mathrm{~cm}$ and $100-300 \mathrm{~cm}$ ). Using such a poorly resolved soil model to calculate the active layer thickness introduces biases in the estimate of the active layer (Burke et al., 2012). This is illustrated in Fig. 1, which compares the active layer thickness interpolated from a standard 4-layer model set up with that interpolated from a 70-layer soil model, with each layer $10 \mathrm{~cm}$ thick. Interpolation of output from this latter model is assumed to reproduce the active layer more accurately. These model simulations are pan Arctic simulations from the Joint UK Land Environment Simulator (JULES: Best et al., 2011; Clark et al., 2011), which is comparable to the land surface component of the Hadley Centre climate model. They were driven by observed global meteorological forcing data over the period 1960-2001. These simulations are described in further detail by Burke et al. (2012). Figure 1 shows that, when compared with the 70-layer soil model, the 4-layer soil model systematically overestimates the active layer thickness for depths between $\sim 1$ and $1.9 \mathrm{~m}$ and systematically underestimates it for depths greater than $2 \mathrm{~m}$. The solid black curve through the points represents the bias in the relationship between the two versions of the model. This was applied as a correction factor to remove the bias in the active layer caused by interpolation from the 4-layer soil model. Any grid cell which has a corrected active layer of greater than $3 \mathrm{~m}$ for the period 1861-1890 was assumed to have no near surface permafrost and was excluded in any subsequent analysis.

Figure 2 compares representative time series of the original 4-layer active layer thickness, the corrected 4-layer active thickness and the 70-layer active layer thickness for the JULES simulations discussed above and in Burke et al. (2012). These are time series for a north-south transect at $65^{\circ} \mathrm{E}$. Using the correction factor significantly improves the estimate of the active layer thickness for depths less than $\sim 1.7 \mathrm{~m}$. However, it makes little differences to the accuracy of the active layer thickness for depths $\sim 2 \mathrm{~m}$ or more. When the active layer reaches $\sim 2 \mathrm{~m}$, it often remains there for several years before abruptly disappearing rather than gradually increasing as for the 70-layer model (Fig. 2a). However, this near surface permafrost disappears at about the same time that the active layer in the 70-layer model becomes permanently deeper than $3 \mathrm{~m}$. Therefore, although the vulnerable soil carbon would be underestimated during the period 19601988 it would all become available in 1988. This suggests that any large-scale estimate of vulnerable carbon using these corrected active layer thicknesses are biased by low produc-

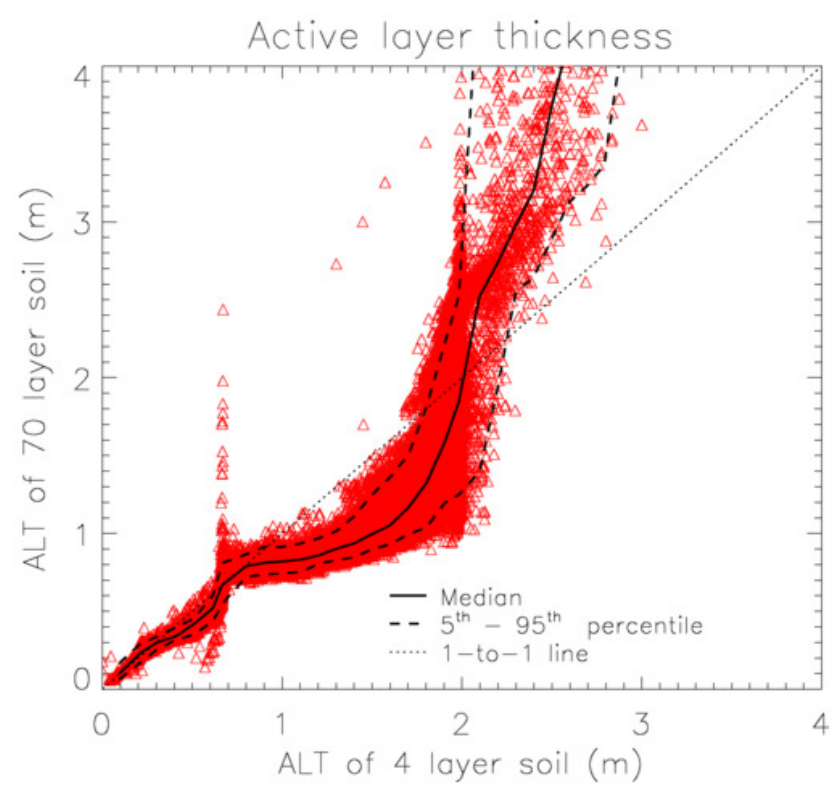

Fig. 1. The correction factor applied to the HadGEM2-ES output to reduce the bias in the estimation of the active layer thickness.

ing carbon decomposition rates which are too slow. This needs to be rectified in the future, for example, by changing the thicknesses of the soil layers within HadGEM2-ES.

The main source of climate modelling uncertainty considered in this paper is caused by the four different RCP scenarios. Another notable source of uncertainty between climate model simulations arises from errors in the representation of relevant model processes (Murphy et al., 2004). A detailed assessment of this uncertainty is beyond the scope of this paper, but it is unlikely to be significantly more than the uncertainty resulting from the different RCP scenarios.

\subsection{Vulnerable carbon}

As the global temperature increases and the active layer increases, the soil organic carbon which is no longer permanently frozen becomes vulnerable to decomposition. The amount of soil organic carbon present was estimated using the Northern Circumpolar Soil Carbon Database (NCSCD - Tarnocai et al., 2009). In general, soil carbon in the NCSCD is severely under-sampled, particularly at depths greater than $100 \mathrm{~cm}$. For example, the soil organic carbon content (SOCC) for the 100-300 cm was estimated using 45 pedons, only a handful of which were from Eurasia (Tarnocai et al., 2009). Kuhry et al. (2010) present some comparisons between the NSCSD and regional scale studies of SOCC. In one case the NCSCD is $45 \%$ higher (Usa Basin, Russia) than regional estimates and in another $37 \%$ lower (Tulemalu, Canada). These large differences combined with small sampling sizes indicate that the uncertainties in any estimates of SOCC are potentially large. 

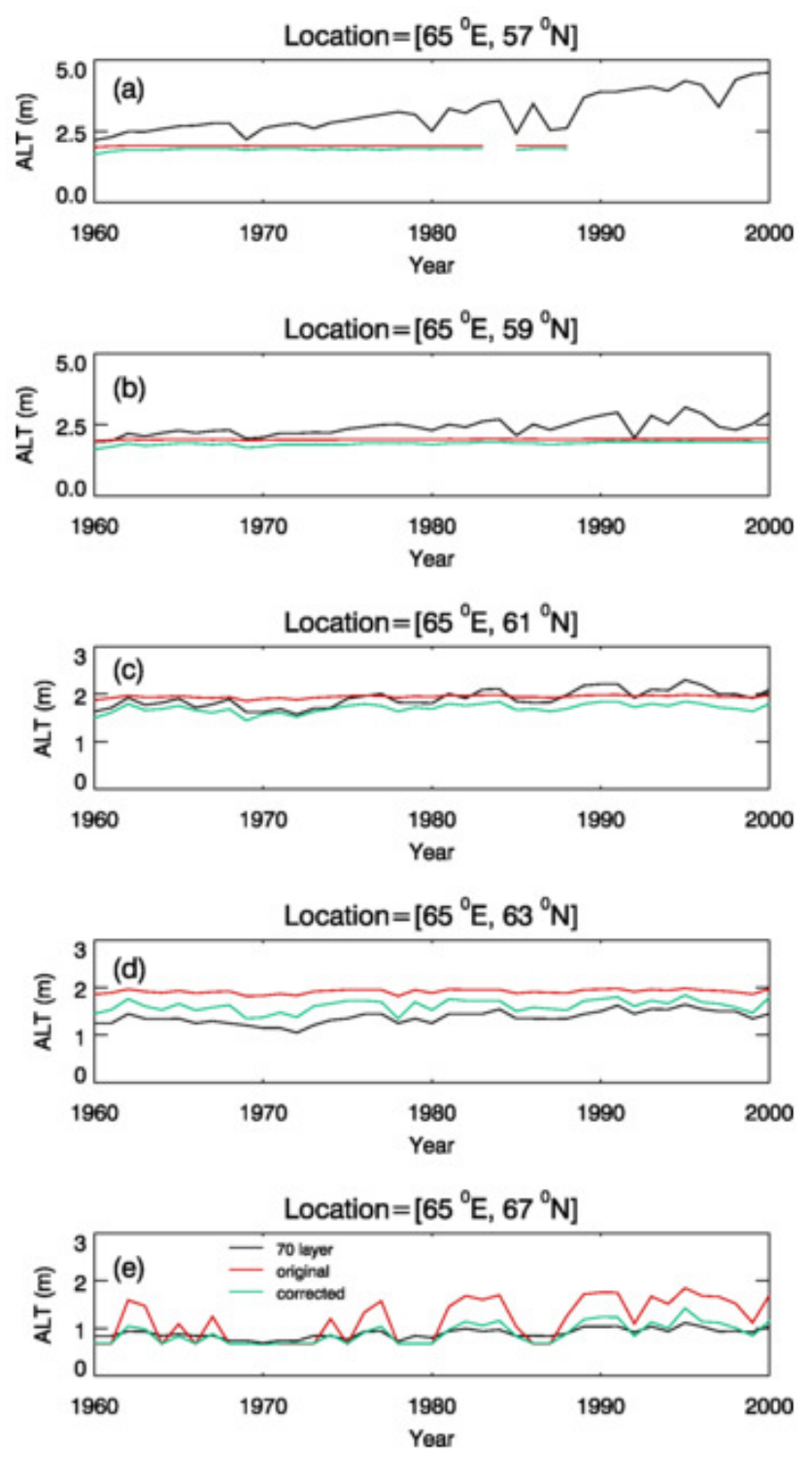

Fig. 2. The simulated active layer thicknesses for a selected southnorth transect at $65^{\circ} \mathrm{E}$. The 70-layer simulated active layer is shown (in black) along with the original 4-layer active layer (in red) and the corrected 4-layer active layer (in green). Note difference in scale between $(\mathbf{a}, \mathbf{b})$ and $(\mathbf{c}-\mathbf{e})$.

Tarnocai et al. (2009) provide an estimate of SOCC for a depth of $0-100 \mathrm{~cm}$, but they do not map uncertainties on this estimate or map the SOCC for depths of $100-200 \mathrm{~cm}$ and $200-300 \mathrm{~cm}$. However, Table 4 of Tarnocai et al. (2009) provides the mean SOCC and its standard deviation for each of the dominant northern high latitude soil types. This information was used as the basis for estimating the spatial distribution of the uncertainties in the SOCC for the top $100 \mathrm{~cm}$, given the knowledge of the area occupied by each soil type. It was assumed that the SOCC for each soil type fell somewhere within the mean \pm 0.75 of the standard deviation of that soil type. This uncertainty was sampled independently for seven soils (Histels, Orthels, Turbels, Histosols, Mollisols, Spodosols and Inceptisols). These soils represent soils which contain the majority of permafrost organic carbon. This uncertainty was also sampled independently in four regions (Europe, Canada, Russia and Alaska). It was assumed that the uncertainty in the SOCC in the other regions was a negligibly small fraction of the total permafrost soil organic carbon and neglected. It was also assumed that the SOCC for $100-200 \mathrm{~cm}$ has a similar spatial distribution to that for 0 $100 \mathrm{~cm}$ but is reduced by a spatially independent proportion, which was randomly sampled from $0.5-0.9$ of the SOCC in the top $100 \mathrm{~cm}$ (Table 1: soil SOC reduction $100-200 \mathrm{~cm}$ ). For depths greater than $200 \mathrm{~cm}$, it was assumed that the only soils with any significant soil organic carbon were Turbels, Histels and Histosols. They were assumed to contain a (spatially independent) fraction of the amount between 100 and $200 \mathrm{~cm}$, which was randomly sampled from between $0.4-0.8$ (Table 1: soil SOC reduction $200-300 \mathrm{~cm}$ ).

In order to determine the permafrost soil carbon vulnerable to decomposition, the amount of additional thawed permafrost carbon in any particular year was estimated. For each grid cell the active layer of the baseline period, in this case 1861-1890, was defined as the maximum thaw depth during that period. The SOCC of the soil at depths shallower than this maximum thaw depth was assumed to be already present in the carbon cycle and is not considered here. During any year and for any grid cell that the active layer is greater than the baseline, there is permafrost carbon vulnerable to decomposition. The amount of vulnerable carbon is the SOCC of the soil between the maximum thaw depth of the current year and the baseline active layer thickness.

\subsection{Decomposition of vulnerable carbon}

A highly simplistic large-scale model for the release of permafrost soil carbon to the atmosphere is proposed here. It is assumed that there are no new inputs of carbon into the thawed permafrost and all vulnerable carbon is thawed permafrost carbon. The vulnerable soil carbon is assigned to pools which decompose into either $\mathrm{CO}_{2}$ or $\mathrm{CH}_{4}$ depending on whether the process is anaerobic or aerobic. Any $\mathrm{CH}_{4}$ may undergo some oxidation before being released to the atmosphere. The model parameter ranges were assigned following the spread of values found in the literature and are summarised in the top half of Table 1 . The parameters about which there is little information were assigned wider ranges.

\subsubsection{Soil organic carbon pools}

Following Dutta et al. (2006) the vulnerable carbon is assigned to three carbon pools. The passive pool is very stable, and any carbon in this pool is not released over the timescale of this study. The active pool decomposes almost immediately as the permafrost thaws. The final pool is denoted the 
Table 1. Spread of values for simple modelling framework.

\begin{tabular}{lrr}
\hline & $\begin{array}{r}\text { Lower } \\
\text { value }\end{array}$ & $\begin{array}{r}\text { Upper } \\
\text { value }\end{array}$ \\
\hline Soil SOCC reduction $(100-200 \mathrm{~cm})$ & 0.5 & 0.9 \\
Soil SOCC reduction $(200-300 \mathrm{~cm})$ & 0.4 & 0.8 \\
Slow pool (\% total SOC) & 10 & 60 \\
Fast pool (\% total SOC) & 0 & 5 \\
Aerobic decomposition rate & 0.03 & 0.5 \\
${\text { (mg } \mathrm{Cg}^{-1} \text { soil C day }}^{-1}$ ) & & \\
Anaerobic decomposition rate $\mathrm{CO}_{2}$ & 5 & 70 \\
${\text { ( } \mu \mathrm{g} \mathrm{C}^{-1} \text { soil C day }}^{-1}$ ) & & \\
Anaerobic decomposition rate $\mathrm{CH}_{4}$ & 0.1 & 15 \\
${\text { ( } \mu \mathrm{g} \mathrm{C}^{-1} \text { soil C day }}^{-1}$ ) & & \\
Lowland proportion respired aerobic $_{\text {Upland proportion respired aerobic }}$ & 0.0 & 0.3 \\
Proportion methane oxidized wetlands & 0.7 & 1.0 \\
Proportion methane oxidized lakes & 0.1 & 0.7 \\
Proportion methane oxidized mesic & 0.0 & 0.3 \\
\hline
\end{tabular}

slow pool. In this pool the soil carbon decays at a rate which depends on the length of time the permafrost is thawed, the amount of vulnerable carbon in the pool, and some specified decomposition rates. In years when the active layer reaches a new maximum all of the carbon in the slow pool is available for decomposition. In years when the active layer is less than the baseline, none of the slow pool is available for decomposition. In all other years a proportion of the slow pool is available for decomposition depending on the how deep the active layer thickness is compared to the baseline and its historic maximum. It is assumed that there is no transfer of soil carbon between these three pools.

Dutta et al. (2006) used laboratory incubations on yedoma soils, and estimated the passive pool to be $18 \%$ and the active pool to be $3 \%$ of the total soil carbon. Following a literature review, Falloon et al. (1998) suggested that the passive pool could be much larger and range between 15 and $60 \%$. However, they did not include any permafrost soils. If the organic carbon was originally incorporated into the permafrost and frozen relatively quickly, as was the case for yedoma soils, neither the slow pool nor the active pool will have significantly decomposed. Therefore, it is suggested that the estimates of Dutta et al. (2006) provide a lower limit for the passive pool and an upper limit for the active pool. The estimates of Falloon et al. (1998) can be assumed to provide an upper limit for the passive pool. The lower limit of the active pool is assumed to be zero. The slow pool is assumed to contain the remaining fraction of the soil organic carbon.

\subsubsection{Decomposition of the slow pool}

The proportion of the decomposition that occurs anaerobically is mainly dependent on the oxygen availability, which is a function of the relative saturation of the soil. The per- mafrost zone was assumed to fall into one of three systems: an upland system, a wetland system or a lake. Each system has different levels of oxygen availability. The Global Lakes and Wetland Dataset (GLWD - Lehner and Döll, 2004) was used to define the proportion of the model grid cell that could be assigned to each of the three systems. The GLWD is available at $30 \mathrm{~s}$ resolution and was determined from a variety of existing data. Overall, $\sim 9 \%$ of the permafrost soil is defined as wetlands, and $\sim 3 \%$ is defined as lakes, with the remainder uplands. For this analysis of the RCP scenarios, it was assumed that the relative proportions of wetlands, lakes and uplands stay the same in the future. However, this could change considerably in the future. For example, one climate model, HadGEM2-ES, suggests that the area of northern high latitude wetlands decreases by between 5 and $10 \%$ over the course of this century. In an upland system the primary decomposition process is assumed to be aerobic with the vast majority of carbon released as $\mathrm{CO}_{2}$. However, there might be regions of high water content at the bottom of the active layer, or there might be partially or seasonally water logged soils (Hobbie et al., 2000), so a small proportion might decompose anaerobically. In contrast in a wetland system or under lakes, the primary decomposition pathway is assumed to be anaerobic (Frolking et al., 2001). There are however occasional permafrost plateaus within wetlands, particularly in the discontinuous permafrost, where the decomposition is aerobic.

Aerobic decomposition of permafrost carbon is negligibly small when it is frozen but accelerates rapidly when the permafrost carbon thaws. This transition is the primary driver of rate change, and the temperature of the thawed permafrost carbon is a second order effect (Davidson and Janssens, 2006) and thus neglected here. The majority of studies that have examined the decomposability of soil organic carbon stored in permafrost soil were carried out in highly controlled laboratory conditions. Measured aerobic decomposition rates range between 0.03 and $0.5 \mathrm{mg} \mathrm{C} \mathrm{g}^{-1}$ soil $\mathrm{C} \mathrm{day}^{-1}$ (Ulhirová et al., 2007; Waldrop et al., 2010; Dutta et al., 2006; Turetsky et al., 2002; Hollesen et al., 2011; Michaelson and Ping, 2003; Lee et al., 2012). Although not all of the measurements are from below the maximum thaw depth, Uhlirová et al. (2007) suggest that rates at those depths are very similar to those within the active layer. These data only represent a very few point sites within a limited range of soil types and land cover. Anaerobic soil decomposition rates are highly suppressed compared with aerobic rates (Lee et al., 2012; Waldrop et al., 2010). Available measurements of these rates are much more limited and range between 0.1 and $15 \mu \mathrm{g} \mathrm{Cg}^{-1}$ soil $\mathrm{Cday}^{-1}$ for $\mathrm{CH}_{4}$ production and 5 and $70 \mu \mathrm{g} \mathrm{Cg}^{-1}$ soil $\mathrm{C} \mathrm{day}^{-1}$ for $\mathrm{CO}_{2}$ production.

Decomposition will occur at the base of the active layer, and therefore any $\mathrm{CH}_{4}$ produced may be oxidized to $\mathrm{CO}_{2}$ before it is released into the atmosphere. This process is highly dependent on whether $\mathrm{CH}_{4}$ reaches the atmosphere by slow diffusion, faster ebullition or transport through the vascular 
system of plants (Schimel, 1995). The relative proportion of $\mathrm{CH}_{4}$ transported through each of these pathways is dependent on the depth of the water table as well as the presence of vascular plants. In upland systems without vascular plants, it is possible that all of the $\mathrm{CH}_{4}$ is oxidized before reaching the surface (Shea, 2011). In wetlands a lower proportion of the $\mathrm{CH}_{4}$ is oxidized because of the presence of vascular plants and an increased occurrence of ebullition. Over thaw lakes, where the water table is above the surface, the majority of $\mathrm{CH}_{4}$ is released via ebullition, and there is little opportunity for oxidation (Walter et al., 2006).

\subsubsection{Impact of released carbon on the global temperature}

The release of the thawed permafrost carbon into the atmosphere will cause an increase in the global mean temperature (P-GMT).

A change in the global mean temperature can be estimated from a change in the radiative forcing using the very simple climate energy balance model shown in Eq. (1).

$C \frac{\partial \Delta T(t)}{\partial t}+\lambda \Delta T(t)=\Delta Q(t)$,

where $\Delta T$ is the global surface temperature anomaly in $\mathrm{K}$; $\lambda$ is the climate feedback parameter in $\mathrm{W} \mathrm{m}^{-2} \mathrm{~K}^{-1} ; C$ is an effective ocean heat capacity in $\mathrm{J} \mathrm{m}^{-2} \mathrm{~K}^{-1} ; Q$ is the radiative forcing; and $t$ is time. Equation (1) shows the ocean heat uptake and change in global mean temperature is balanced by the change in radiative forcing. The parameters $\lambda$ and $C$ are found using a HadGEM2 climate simulation where the radiative forcing is known and increased by $1 \%$ per year.

In the case of no permafrost, the change in radiative forcing of each of the HadGEM2-ES RCP simulations was determined from the change in $\mathrm{CO}_{2}$ concentration in the atmosphere.

$\Delta Q(t)=5.4 \ln \left(\frac{C_{\mathrm{CO}_{2}}(t)}{C_{\mathrm{CO}_{2}}(t=0)}\right)$,

where $C_{\mathrm{CO}_{2}}(t)$ is the $\mathrm{CO}_{2}$ concentration at time $t$, and $C_{\mathrm{CO}_{2}}(t=0)$ is the mean $\mathrm{CO}_{2}$ concentration for the baseline period. The $\mathrm{CO}_{2}$ concentration for each of the RCP scenarios was calculated by multiplying the simulated emissions by the model-derived airborne fractions.

The $\mathrm{CH}_{4}$ and $\mathrm{CO}_{2}$ emitted by the thawing permafrost carbon result in additional changes in radiative forcing. The extra radiative forcing caused by the increase in $\mathrm{CO}_{2}$ concentration from permafrost carbon release was calculated using a comparable equation to Eq. (2). It was assumed that any change in $\mathrm{CO}_{2}$ emissions as a result of the release of permafrost carbon was a small fraction of the total emissions and did not impact the model-derived airborne fraction. The radiative forcing from the emitted $\mathrm{CH}_{4}$ was calculated from the fractional increase in burden which also accounts for changes in $\mathrm{CH}_{4}$ lifetime. This was then converted into an increase in radiative forcing including the effect on ozone and stratospheric water vapour (Collins et al., 2011a).

The change in global mean temperature was then estimated for each year using the following equation:

$$
\Delta T\left(t_{i}+\Delta t\right)=\frac{\Delta Q\left(t_{i}\right)}{\lambda}+\left(\Delta T\left(t_{i}\right)-\frac{\Delta Q\left(t_{i}\right)}{\lambda}\right) \exp \left(-\frac{\lambda \Delta t}{C}\right)
$$

where $\Delta t$ is one year. Equation (3) can be used to estimate the change in temperature with no permafrost carbon release, the change caused by the $\mathrm{CO}_{2}$ emitted from the thawed permafrost carbon, the change caused by the emitted $\mathrm{CH}_{4}$, and P-GMT, which is the overall increase in temperature from permafrost carbon release.

\subsection{Methodology}

This simple modelling framework for estimating the increase in global mean temperature caused by permafrost carbon release (P-GMT) has many uncertain parameters. In order to determine the range of plausible P-GMT changes, 4000 Monte Carlo simulations were carried out for each RCP scenario. For each set of simulations both the model parameters and SOCC were randomly sampled from a uniform distribution using a Latin hypercube sampling (LHS) strategy and the ranges shown in Table 1. LHS allows interactions between different parameter combinations to be studied. Therefore, the 16000 simulations can subsequently be used to identify the contributions of parameters alone and in combination to the uncertainty in P-GMT.

The contribution of each parameter to the range of P-GMT was determined by splitting the parameter values into a set of bins and for each bin calculating the mean and standard deviation of P-GMT. This was then compared with the mean and standard deviation of P-GMT for all of the 16000 simulations. If P-GMT is sensitive to a parameter, there will be notable differences between the mean and standard deviation of P-GMT in each bin and that for all of the 16000 simulations. This can be quantified using the following equation:

$S=\frac{1}{N} \sum_{i=1}^{N} \frac{\left(\mu_{i}-\mu\right)^{2}}{\sigma^{2}}$,

where $\mu_{i}$ is the mean of bin $i ; \mu$ is the mean of all the simulations; and $\sigma$ is the standard deviation of all of the simulations.

\section{Results}

\subsection{Simulation of global temperature change}

Figure 3 shows the mean permafrost extent simulated by HadGEM2-ES for the period 1900-1910. This is the area where there is permafrost within the top $3 \mathrm{~m}$. HadGEM2ES simulates 23.8 million $\mathrm{km}^{2}$. Zhang et al. (2003) estimate 

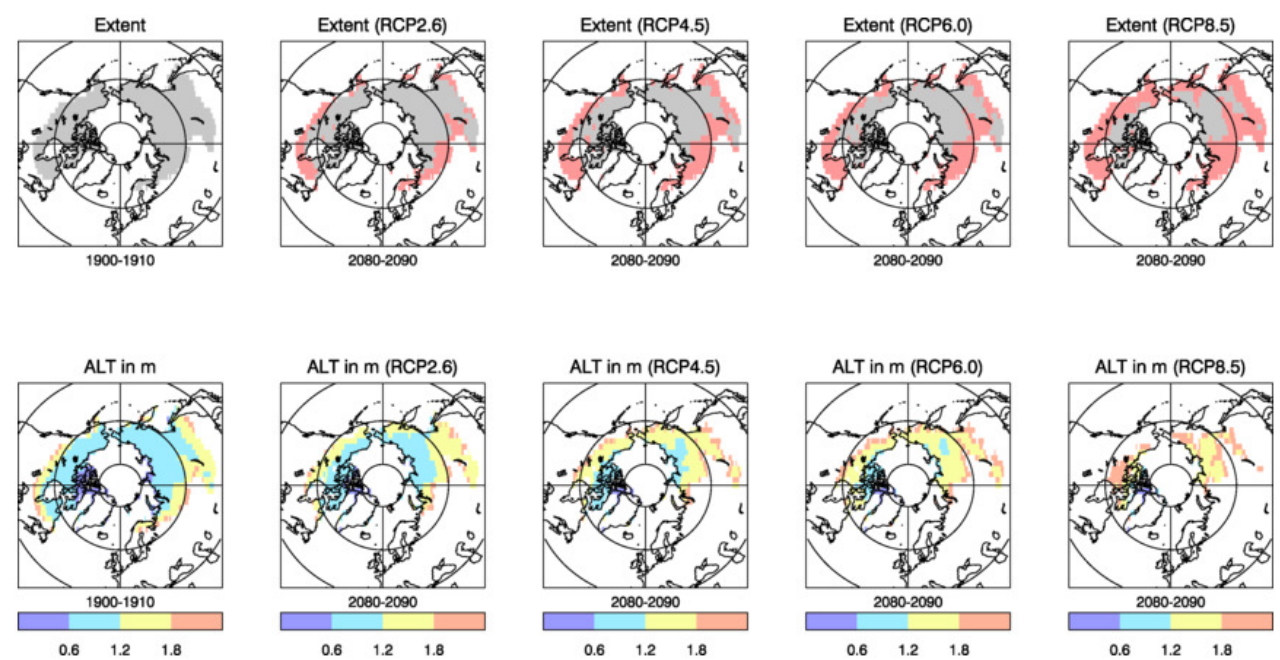

Fig. 3. Mean permafrost extent and active layer thickness (ALT) for 1900-1910 and for 2080-2090, modelled by HadGEM2-ES for the four RCP pathways. In the plots of permafrost extent (top row), the red shows the places where there is no longer permafrost in the top $3 \mathrm{~m}$.

the permafrost affected area to be 22.79 million $\mathrm{km}^{2}$. However, because permafrost does not exist everywhere in permafrost regions, they estimate that it actually underlies only between 12.2 and 17.0 million $\mathrm{km}^{2}$ of the exposed land area. Therefore, HadGEM2-ES overestimates the permafrost extent. One of the reasons for this difference is errors in the HadGEM2-ES surface climate. Another reason is deficiencies in the single layer snow scheme used in HadGEM2ES. Use of a multi-layer snow scheme significantly reduces the model simulation of permafrost extent in the land surface scheme (JULES: Burke et al., 2012). However, Burke et al. (2012) showed that the simulated rate of decrease of the permafrost extent during the 20th century was comparable for both snow schemes and generally independent of the simulated extent. JULES, when driven by observed meteorology, simulates an active layer that is too deep (Dankers et al., 2011). This is mainly caused by errors in the representation of the thermal conductivity both at the surface and within the active layer during the summer thaw period. However, JULES can generally represent year-to-year changes in the active layer thickness (Burke et al., 2012). Future developments within JULES will address deficiencies in the key insulation processes at and below the land surface.

As might be expected from the increase in the simulated global mean temperature, the permafrost extent decreases and the active layer deepens over the 21st century for each of the RCP scenarios. By the 2080s the simulated nearsurface extent has decreased to 17.6 million $\mathrm{km}^{2}$ for RCP2.6, 14.1 million $\mathrm{km}^{2}$ for RCP4.5, 13.6 million $\mathrm{km}^{2}$ for RCP6.0, and 8.5 million $\mathrm{km}^{2}$ for RCP8.5. This represents a loss of between $25 \%$ and $65 \%$, depending on the scenario. This loss is slightly less than that projected by Lawrence and Slater (2005) but larger than that projected by Schaefer et al. (2011). The mean simulated active layer thickness of the permafrost remaining at the end of 21st century is $1.62 \mathrm{~m}$ for the RCP8.5 scenario. Masking the permafrost of the other scenarios and the present day by the RCP8.5 extent gives a present day active layer thickness of $0.69 \mathrm{~m}$ and an increase in the mean active layer thickness to $0.93 \mathrm{~m}$ for RCP2.6, $1.14 \mathrm{~m}$ for RCP4.5, and $1.28 \mathrm{~m}$ for RCP6.0. This is an overall increase of between 24 and $59 \mathrm{~cm}$ depending on scenario. This falls within the range of values reviewed by Schaefer et al. (2011).

The time series of vulnerable carbon, defined as the permafrost carbon which becomes thawed for some period of each year, is shown in Fig. 4. The solid lines show the vulnerable soil carbon using the SOCC for $0-100 \mathrm{~cm}$ from Tarnocai et al. (2009). The SOCC at a depth of 100-200 cm (Table 1: soil SOC reduction for $100-200 \mathrm{~cm}$ ) was set to 0.8 of the $0-100 \mathrm{~cm}$ distribution, and the SOCC at a depth of 200$300 \mathrm{~cm}$ (Table 1: soil SOC reduction for $200-300 \mathrm{~cm}$ ) was set to 0.7 of the $100-200 \mathrm{~cm}$ distribution for Turbels, Histels and Histosols, and zero for the other soil types. This gives a total SOCC of $951 \mathrm{Pg}$ in the top $300 \mathrm{~cm}$ of the HadGEM2ES simulated permafrost regions. This is comparable with the $1024 \mathrm{Pg}$ suggested by Tarnocai et al. (2009). The minimum/maximum of the vulnerable carbon were found by reducing/increasing mean SOCC to their minima/maxima (see Sect. 2.3) and using the minimum/maximum of the soil SOC reduction factors shown Table 1. Including these uncertainties give a total SOCC in the top $300 \mathrm{~cm}$ of the HadGEM2ES permafrost region of between 313 and $1803 \mathrm{Pg}$. These cover a wide range of SOCC, which represents the large uncertainty on the Tarnocai et al. (2009) estimate. Figure 4 also shows a wide range of vulnerable carbon. For the RCP8.5 scenario, the spread in vulnerable carbon is large, ranging from $75 \mathrm{Pg}$ to $870 \mathrm{Pg}$ by 2100 . Even for the RCP2.6 


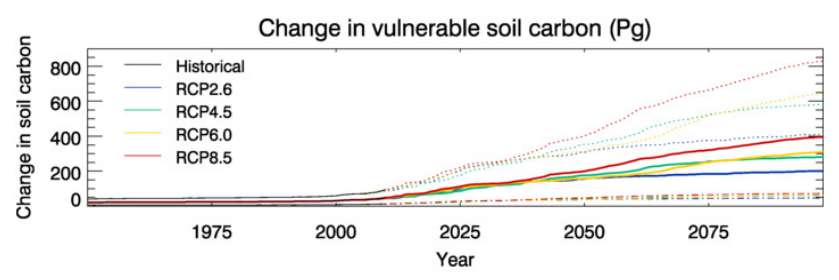

Fig. 4. Time series of vulnerable soil carbon for the four RCP scenarios. The solid lines show the vulnerable carbon using the soil organic carbon contents from Tarnocai et al. (2009), the dotted lines use the maximum soil organic carbon content used within the Monte Carlo simulations, and the dashed lines the minimum.

mitigation scenario, there is still a notable amount of vulnerable carbon - between 45 and $400 \mathrm{Pg}$.

The amount of vulnerable carbon added to the carbon cycle in each year depends on how long the permafrost is thawed. This is primarily in the form of $\mathrm{CO}_{2}$ and $\mathrm{CH}_{4}$ released to the atmosphere. Figure 5a (top panel) shows the annual emissions of $\mathrm{CO}_{2}$ released from the thawed permafrost, calculated using Monte Carlo simulations of the permafrost carbon decomposition model. The full spread of values is large, with annual emission rates ranging from near zero to over $7 \mathrm{PgC}$ per year as $\mathrm{CO}_{2}$, although the majority of the simulations fall within 0.5 to $4 \mathrm{Pg} \mathrm{C}$ per year (5th-95th percentile). Dutta et al. (2006) extrapolated from point measurements for yedoma and suggest an emission rate of permafrost carbon of $1 \mathrm{PgC} \mathrm{yr}^{-1}$, which falls towards the low end of this range. Current fossil fuel emissions are estimated to be $\sim 8$ $9 \mathrm{Pg} \mathrm{C} \mathrm{yr}^{-1}$. However, by 2100 they are projected to rise to over $20 \mathrm{PgC}$ per year for RCP8.5 and fall to $\sim 3 \mathrm{PgC}$ per year for RCP4.5. Therefore, the release of $\mathrm{CO}_{2}$ from permafrost carbon has the potential to contribute significantly to the total annual $\mathrm{CO}_{2}$ emission rates by 2100 , particularly for the two mitigation scenarios. Figure $5 \mathrm{~b}-\mathrm{e}$ (lower 4 pannels) show the cumulative emissions of $\mathrm{CO}_{2}$. All 16000 of the Monte Carlo simulations are shown in grey and are plausible. In addition, the 5th-95th percentile ranges are shown to the right of the figures. For the RCP8.5 scenario and by the end of the 21 st century, there could be between 50 and $250 \mathrm{Pg}$ of $\mathrm{C}$ from permafrost released into the atmosphere in the form of $\mathrm{CO}_{2}$ (5th-95th percentile range). The range of permafrost carbon emissions found by Schaefer et al. (2011), Schneider von Deimling (2012), Zhuang et al. (2006), and Koven et al. (2011) under comparable high emissions scenarios fall within, albeit mainly to the lower limit of, this spread. For RCP8.5 the permafrost carbon $\mathrm{CO}_{2}$ emissions are a relatively small percentage - between 2 and $13 \%$ - of the projected fossil fuel emissions. Cumulative emissions are lower for the other scenarios, but the percentage of the projected fossil fuel emissions increases; for example, the 20$80 \mathrm{Pg} \mathrm{C}$ released for RCP2.6 is 5-20\% of the projected fossil fuel emissions. Emission rates for $\mathrm{CH}_{4}$ are lower, reaching from near negligible to over $0.1 \mathrm{PgC}$ per year $\left(133 \mathrm{Tg} \mathrm{CH}_{4}\right.$
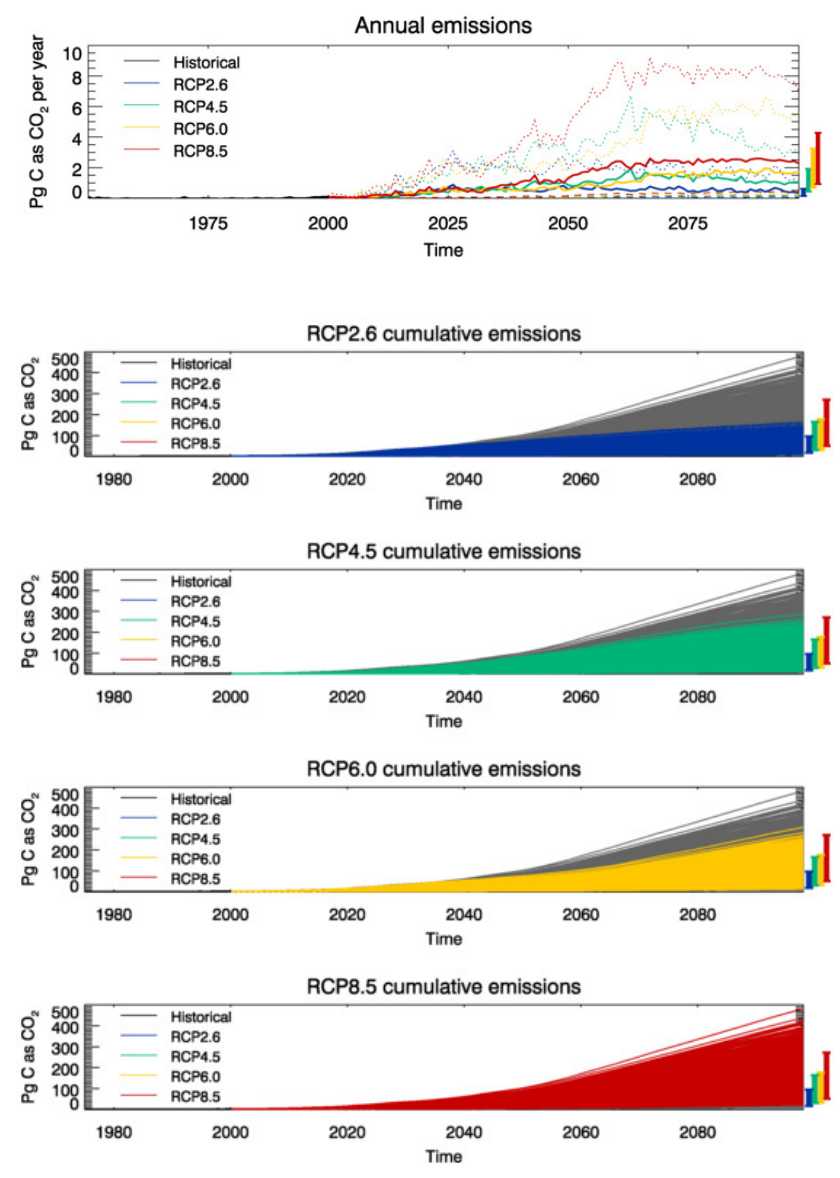

Fig. 5. Time series of $\mathrm{CO}_{2}$ emissions. (a) Shows the annual $\mathrm{CO}_{2}$ emissions for the 4 RCP scenarios. The solid lines show the median and the dotted and the dashed lines show the full spread of values. The bottom 4 panels show the time series of the cumulative $\mathrm{CO}_{2}$ emissions for each RCP. The grey lines represent the full spread of values from the 16000 Monte Carlo simulations irrespective of RCP. In all panels the bars at the right hand side show the 5th-95th percentile values.

per year) by 2100 (Fig. 6). The majority of the simulations give emission rates below $0.04 \mathrm{PgC}$ per year, or $53 \mathrm{Tg} \mathrm{CH}_{4}$ per year. At present, the northern high latitudes $\left(>45^{\circ} \mathrm{N}\right)$ is estimated to be a source of $\mathrm{CH}_{4}$ to the atmosphere of around 40-50 Tg $\mathrm{CH}_{4} \mathrm{yr}^{-1}$ (Bloom et al., 2010; Zhuang et al., 2004). This is predominantly wetland emissions. Our results suggest that in the future the release of permafrost carbon in the form of $\mathrm{CH}_{4}$ could be similar in magnitude to the current northern high latitude wetland emissions.

Figure 7 show the wide spread in P-GMT. All values in grey are plausible. For RCP8.5, P-GMT ranges between 0.08 and $0.36^{\circ} \mathrm{C}$ by 2100 (5th-95th percentile). Although this is slightly larger than the additional warming of 0.04 to $0.23^{\circ} \mathrm{C}$ ( $68 \%$ range) estimated by Schneider von Deimling (2012) for the same RCP, some of these differences, particularly in the upper bounds, arise because the ranges 


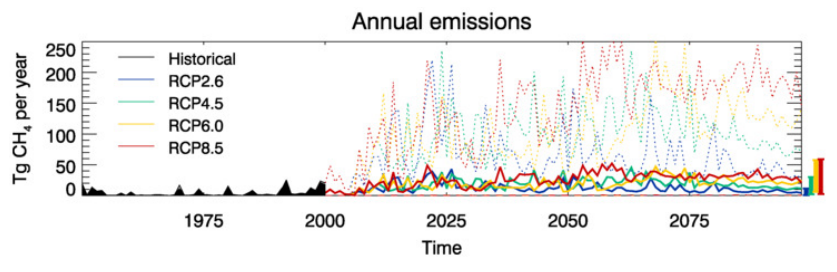

Fig. 6. Time series of annual $\mathrm{CH}_{4}$ emissions for the $4 \mathrm{RCP}$ scenarios in $\mathrm{TgCH}_{4}$ per year. The solid lines show the median and dotted and dashed lines show the full spread of values, whilst the bars to the right of the plot show the 5th-95th percentile ranges.
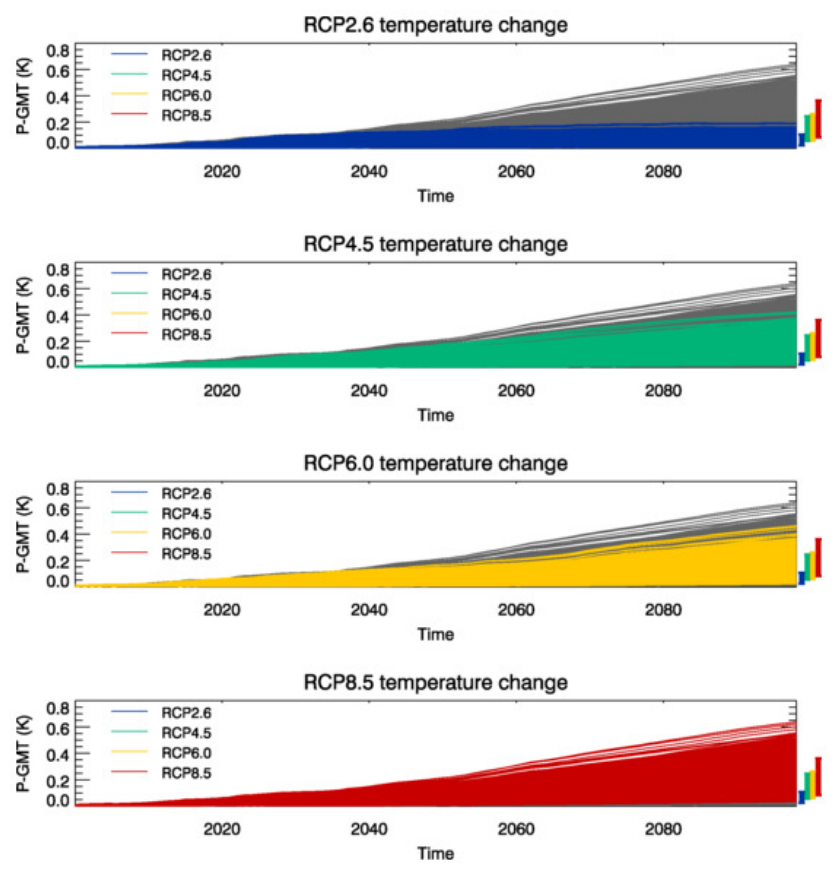

Fig. 7. Time series of the temperature change caused by the permafrost $\mathrm{CO}_{2}$ and $\mathrm{CH}_{4}$ emissions for the $4 \mathrm{RCP}$ scenarios (P-GMT). The bars at the right-hand side show the 5th-95th percentile values.

quoted are not directly comparable. The temperature change for RCP4.5 and RCP6.0 scenarios are similar to each other and only slightly larger than those estimated by Schneider von Deimling (2012), at between 0.05 and 0.28 for a $68 \%$ range. Those from RCP2.6 are considerably lower. Overall, P-GMT is about $2-4 \%$ of the temperature increase simulated by HadGEM2-ES without permafrost carbon release.

Figure 8 shows how the relative contribution of $\mathrm{CH}_{4}$ and $\mathrm{CO}_{2}$ to the total of P-GMT changes over time. During the pe$\operatorname{riod} 2010$ to 2040, the $\mathrm{CH}_{4}$ emissions drive any (albeit small) increases in P-GMT, with the impact of $\mathrm{CH}_{4}$ on temperature peaking at more than twice the impact of $\mathrm{CO}_{2}$. Towards the end of the 21 st century, the relatively short $\mathrm{CH}_{4}$ atmospheric lifetime combined with the larger $\mathrm{CO}_{2}$ emissions mean that the $\mathrm{CO}_{2}$ emissions rather than the $\mathrm{CH}_{4}$ emissions drive the overall temperature increase. However, by $2100,1 / 4$ of the

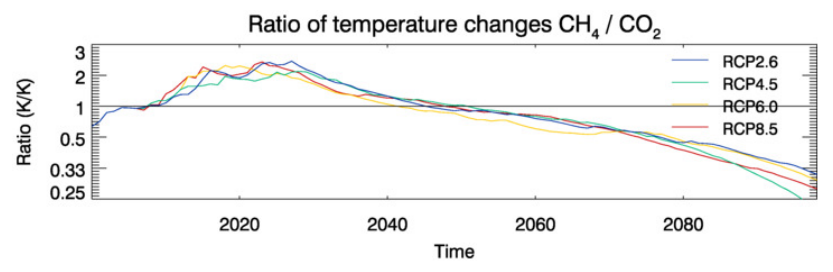

Fig. 8. Time series of the median of the ratio of the proportion of P-GMT caused by $\mathrm{CH}_{4}$ to that caused by $\mathrm{CO}_{2}$.

temperature increase is still caused by $\mathrm{CH}_{4}$. The ratio of the temperature changes from $\mathrm{CH}_{4}$ to $\mathrm{CO}_{2}$ is relatively independent of scenario. On further investigation it was found to be more sensitive to the aerobic decomposition rate used within the carbon decomposition model and also, but less, sensitive to the anaerobic rate.

\section{Uncertainty assessment}

The Monte Carlo simulations can be used to determine the relative importance of the different processes/parameters on the value of P-GMT. Figure 9 compares the relative uncertainties in 2100 caused by the distribution of the soil organic carbon, the quality of the carbon, the RCP simulations, and the decomposition model parameters. The grey lines and error bars in Fig. 9 represent the mean and standard deviation for the whole ensemble (16000 members). The coloured lines and error bars represent the means for $\sim 4000$ simulations which have been grouped by bins around the values shown. For each uncertain process/parameter, its relative importance was calculated using Eq. (4). Figure 9 shows the 12 most uncertain parameters/processes in order of decreasing importance. By 2100, limited knowledge of the RCP scenario causes the most uncertainty. This is $\sim$ five times more important than knowing the reduction in the soil organic carbon content at a depth of 100 and $200 \mathrm{~cm}$ (when compared with the top $100 \mathrm{~cm}$ ). Other relatively important factors include knowledge of the amount of soil carbon in the passive pool, the aerobic decomposition rate and the reduction in the soil organic carbon content at a depth of 200 and $300 \mathrm{~cm}$ (compared with the top $100 \mathrm{~cm}$ ). Knowing the organic carbon content in the Russian Turbels is $\sim 10$ times less important than knowing the reduction of the soil organic carbon content at a depth of 100 and $200 \mathrm{~cm}$. Figure 9 shows the four most important soils are Russian Turbels and Histels, Canadian Turbels, and Alaskan Turbels. Despite containing the largest total amount of soil organic carbon, the Canadian Histosols are not on this top 12. There may be several reasons for this including the relative magnitudes of the uncertainties in the soil organic carbon content measurements, the size of the change in the active layer for these soils, and the location of the different soil types with respect to the wetlands and uplands. 

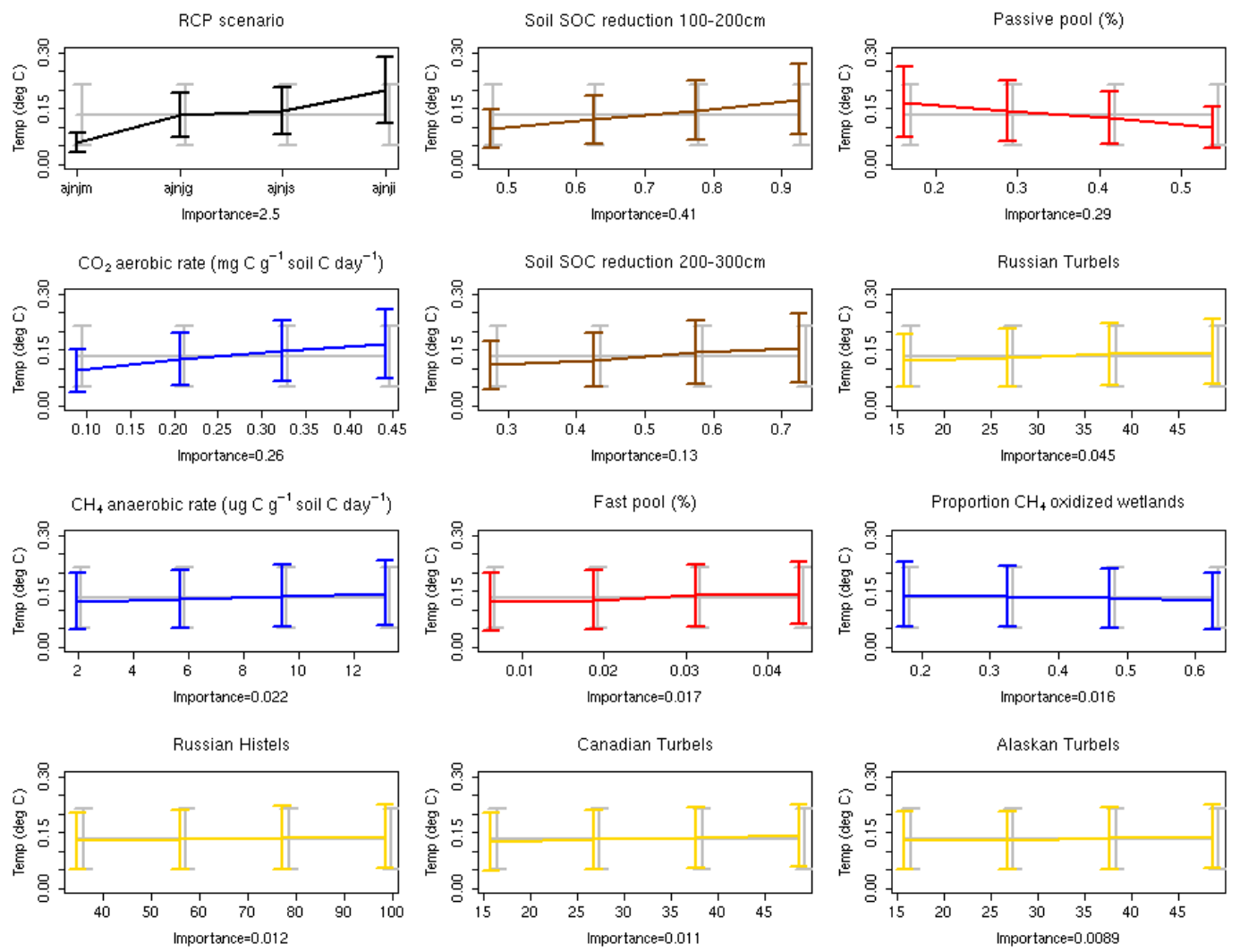

Fig. 9. Sensitivity of the Monte Carlo simulations to the most important model parameters/processes. The grey lines represent the mean and standard deviation of the whole ensemble and the coloured lines the mean and standard deviation sampled around each parameter value. The parameters/processes are sorted in order of decreasing importance.

The importance of each uncertain parameter/process can be calculated every year to determine how their relative importance changes over time (Fig. 10). Near the beginning of the 21 st century, P-GMT is very small with a relative small spread in values. Both of these increase throughout the time period shown. Any differences between the RCP scenarios near the beginning of the 21 st century are small. However, by 2060 they start to grow quickly. Since the future $\mathrm{CO}_{2}$ pathway is hard to determine and depends on many unpredictable factors, this uncertainty is difficult to reduce. Uncertainties in the permafrost parameters/processes are more readily quantified. At the beginning of the 21 st century, when P-GMT is smallest, knowing the quality of the available carbon is most important and contributes to the majority of the spread in P-GMT. This is because the carbon from the fast pool is quickly emitted within the first season that the permafrost is thawed, and there has been no build up of carbon within the slow pool. In the medium term, by the middle of the $21 \mathrm{st}$ century, knowing the distribution of the soil organic carbon content becomes more important. In particular, how it varies with depth. The organic carbon that becomes available as the permafrost thaws is at the bottom of the active layer which increases from an average of $0.69 \mathrm{~m}$. Therefore, in many re- gions the soils of interest are at depths greater than $1 \mathrm{~m}$. By the end of the 21st century, about half the spread in P-GMT is caused by uncertainties in the RCP scenario, a quarter by uncertainties in the soil carbon distribution, an eighth caused by the quality of the soil and an eighth by the parameterisation of the soil decomposition model.

\section{Additional processes and uncertainties}

One source of uncertainty which has not been considered here arises from biases in the HadGEM2-ES present day estimate of permafrost extent and active layer thickness. Overall, HadGEM2-ES simulates too great an extent (suggesting too much permafrost carbon) and too deep a maximum active layer (suggesting too little permafrost carbon in the top $3 \mathrm{~m}$ ). Very approximately, if the simulated extent is assumed to be overestimated by $\sim 1 / 3$ (see Sect. 3.1 above) and the simulated active layer $\sim 1 / 3$ too deep (see Dankers et al., 2011), the large-scale high latitude permafrost volume in the top $3 \mathrm{~m}$ of soil has a relatively small bias. However, this may result in a slightly low estimate of permafrost organic carbon, because the soil organic carbon content generally decreases with increasing depth and decreasing latitudes. In addition, organic 


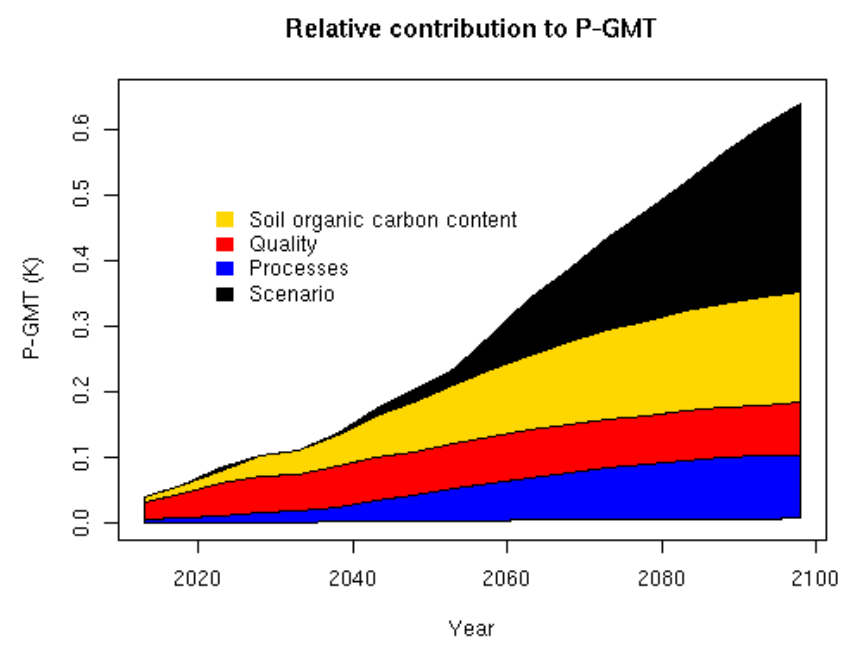

Fig. 10. The relative contribution to the overall spread in P-GMT by the 4 groups of uncertainties examined here: scenario, quality of carbon, distribution of carbon and soil decomposition model parameters.

rich soils are likely to have a greater bias in the simulated active layer than mineral soils, again leading to slight underestimation of permafrost organic carbon. Another important source of uncertainty is the sensitivity of the simulated maximum active layer thickness to the global mean temperature. This uncertainty can be explored further in the context of a multi-model ensemble such as that available for the Coupled Model Intercomparison Project Phase 5 (CMIP5). There are errors in both the present-day simulated active layer thicknesses and their sensitivity to changing temperature because the land surface model does not include a representation of the thermal and hydrological characteristics of organic soils.

The processes included within this framework are highly simplified and do not include any interactions between the carbon currently within the carbon cycle and the thawed permafrost carbon. Many other potentially important processes are yet to be incorporated into this framework. One of the more important processes neglected is thermokarst development. Thermokarst terrain is widespread at high latitudes and it interacts strongly with the local hydrology. Observations suggest that lateral erosion and ground subsidence increase thaw lake area and number in continuous permafrost regions, and drainage decreases them in discontinuous regions (Lee et al., 2012). This is a difficult process to simulate but could cause abrupt permafrost thaw with unpredicted changes in the emission of $\mathrm{CH}_{4}$ and $\mathrm{CO}_{2}$.

Arctic ecosystems will be influenced by the increase in temperature under future climate change, the $\mathrm{CO}_{2}$ fertilization effect, changes in fire frequency, precipitation, and the availability of water in thawed permafrost. These factors will impact the land cover including the abundance and range of the vegetation species and the wetland areas and extent. This will modify both the rates of permafrost thawing and the rate and form of carbon release in a currently unpredictable fashion. Many of these processes are included in some form within the GCM. However, their accuracy depends on the ability of the model to simulate these processes, which is often hard to evaluate at large scales and under climate change. Other relevant processes, which will impact the rate and nature of permafrost degradation and carbon release to a greater or lesser extent, are missing from the land surface component of HadGEM2-ES. These include the formation of ice wedges within the permafrost, cryoturbation, coastal and river erosion, the presence of peat soils, mosses as a vegetation type, and the impact of nitrogen and phosphorous limitation on vegetation productivity. Self-sustaining heat generation by microbial activity is another missing process which could result in long term chronic emissions of $\mathrm{CO}_{2}$ and $\mathrm{CH}_{4}$ (Khvorostyanov et al., 2008). Many of these missing processes are likely to result in more rapid mobilisation of permafrost organic carbon, leading to a larger permafrost carbon response.

In this paper only land permafrost down to a depth of $3 \mathrm{~m}$ is considered. However, yedoma $(407 \mathrm{Pg}$ in depths greater than $3 \mathrm{~m}$ ) and deltaic deposits (241 Pg in depths greater than $3 \mathrm{~m}$ ) both have significant proportions of soil organic carbon (Tarnocai et al., 2009). In addition, subsea permafrost and methane hydrates could also potentially release notable quantities of carbon (O'Connor et al., 2010; Shakhova et al., 2010).

\section{Conclusions}

This paper presents a highly simplistic model of permafrost thaw and subsequent carbon release and demonstrates the impact of the released permafrost carbon on global temperature. Many of the modelled processes have only been explored at limited sites, often using soil cores extracted for laboratory experiments. Although some studies have used carbon isotopic measurements to separate the carbon from the thawed permafrost from carbon already included within the carbon cycle, any large-scale extrapolation to the landscape scale remains challenging. In addition, permafrost degradation can be a slow process which requires systematic observations over many years. Therefore, this simple large-scale model is hard to validate. In order to compensate for that, a large spread of parameter values was used to describe each process resulting in a spread of plausible amount of carbon release and impacts on the global temperature. In the future methods of confronting the model with observations need to be adopted so that the different components of the simple model can be appropriately evaluated.

For the high $\mathrm{CO}_{2}$ concentration pathway, P-GMT is 0.1 to $0.36^{\circ} \mathrm{C}$ by the end of the 21 st century. The proportion of this temperature increase caused by the release of methane is $\sim 0.25$. However, during the early part of the 21 st century when P-GMT is lower (between 0 and $0.1^{\circ} \mathrm{C}$ ), the impact 
of methane on P-GMT is up to 2.5 times the impact of $\mathrm{CO}_{2}$. There are many additional processes, such as thermokarst development, fire, the formation of ice wedges within the permafrost, cryoturbation, coastal and river erosion, the presence of peat soils, and self-sustaining heat generation by microbial activity, which could be included to refine estimates of P-GMT. Observations could be used to help determine which of these processes are potentially significant and need to be included within a modelling framework.

This paper uses the simple framework to assess the sensitivity of the increase in global mean temperature associated with permafrost carbon thaw (P-GMT) to model parameters/processes. During the first part of the 20th century, when P-GMT is small, uncertainties in the quality of the soil have the strongest impact on its value. However, by the end of the 21 st century, P-GMT is much larger and the uncertainties in the RCP scenario cause $\sim 50 \%$ of the overall uncertainty. The distribution of soil organic carbon contributes to about half of the remaining spread in P-GMT with the soil decomposition model and the quality of the organic carbon contributing a quarter each. A reduction of these uncertainties though improved observational-based analysis will improve our estimates of P-GMT. Uncertainties in the sensitivity of the active layer thickness to global mean temperature have not been considered here but are likely to have an impact on P-GMT. However, these are likely to be smaller than the differences between RCP scenarios.

This simple model of permafrost carbon release can be used as a tool to develop an understanding of the impact of permafrost carbon on the global climate system and to help provide an appropriate representation of the permafrost climate feedback within a global circulation model.

Acknowledgements. The work described in this paper was supported by the Joint DECC/Defra Met Office Hadley Centre Climate Programme (GA01101). The authors acknowledge the financial support by the European Union FP7-ENVIRONMENT project PAGE21 under contract no. GA282700. Performing the MOHC CMIP5 simulations was supported by the European Commission's 7th Framework Programme, under Grant Agreement number 226520, COMBINE project.

Edited by: J. Boike

\section{References}

Best, M. J., Pryor, M., Clark, D. B., Rooney, G. G., Essery, R .L. H., Ménard, C. B., Edwards, J. M., Hendry, M. A., Porson, A., Gedney, N., Mercado, L. M., Sitch, S., Blyth, E., Boucher, O., Cox, P. M., Grimmond, C. S. B., and Harding, R. J.: The Joint UK Land Environment Simulator (JULES), model description Part 1: Energy and water fluxes, Geosci. Model Dev., 4, 677-699, doi:10.5194/gmd-4-677-2011, 2011.

Bloom, A. A., P. I. Palmer, A. Fraser, D. S. Reay, and Frankenberg, C.: Large-scale controls of methanogenesis inferred from methane and gravity spaceborne Data, Science, 327, 322-325, doi:10.1126/science.1175176, 2010.

Burke, E. J., Dankers, R. D., and Jones, C. D.: Evaluating changes in near-surface permafrost during the 20th century with the JULES land surface model, Clim. Dynam., in revision, 2012.

Callaghan, T. V., Bergholm, F., Christensen, T. R., Jonasson, C., Kokfelt, U., and Johansson, M.: A new climate era in the subArctic: Accelerating climate changes and multiple impacts, Geophys. Res. Lett., 37, L14705, doi:10.1029/2009GL042064, 2010.

Clark, D. B., Mercado, L. M., Sitch, S., Jones, C. D., Gedney, N., Best, M. J., Pryor, M., Rooney, G. G., Essery, R. L. H., Blyth, E., Boucher, O., Harding, R. J., Huntingford, C., and Cox, P. M.: The Joint UK Land Environment Simulator (JULES), model description - Part 2: Carbon fluxes and vegetation dynamics, Geosci. Model Dev., 4, 701-722, doi:10.5194/gmd-4-701-2011, 2011.

Collins, B., Boucher, O., Jones, C., Totterdell, I., Halloran, P., Woodward, S., O'Connor, F., Bellouin, N., Rumbold, S., Gedney, N., and Gregory, J.: Non- $\mathrm{CO}_{2}$ biogeochemical feedbacks in the HadGEM2 Earth system model, Joint DECC and Defra Met Office Hadley Centre Climate Programme, Reference: DECC/Defra GA01101, February 2011, D2.3.2., 2011a.

Collins, W. J., Bellouin, N., Doutriaux-Boucher, M., Gedney, N., Halloran, P., Hinton, T., Hughes, J., Jones, C. D., Joshi, M., Liddicoat, S., Martin, G., O’Connor, F., Rae, J., Senior, C., Sitch, S., Totterdell, I., Wiltshire, A., and Woodward, S.: Development and evaluation of an Earth-System model - HadGEM2, Geosci. Model Dev., 4, 1051-1075, doi:10.5194/gmd-4-10512011, 2011 b.

Dankers, R., Burke, E. J., and Price, J.: Simulation of permafrost and seasonal thaw depth in the JULES land surface scheme, The Cryosphere, 5, 773-790, doi:10.5194/tc-5-773-2011, 2011.

Davidson, E. A. and Janssens, I. A.: Temperature sensitivity of soil carbon decomposition and feedbacks to climate change, Nature, 440, 165-173, 2006.

Dutta, K., Schuur, E. A. G., Neff, J. C., and Zimov, S. A.: Potential carbon release from permafrost soils of Northeastern Siberia, Glob. Change Biol., 12, 2336-2351, 2006.

Etzelmüller, B., Schuler, T. V., Isaksen, K., Christiansen, H. H., Farbrot, H., and Benestad, R.: Modeling the temperature evolution of Svalbard permafrost during the 20th and 21st century, The Cryosphere, 5, 67-79, doi:10.5194/tc-5-67-2011, 2011

Falloon, P. D., Smith, P., Coleman, K., and Marshall, S.: Estimating the size of the inert organic matter pool from total soil organic carbon content for use in the rothamsted carbon model, Soil Biol. Biochem., 30, 1207-1211, 1998.

Frauenfeld, O. W., Zhang, T., Barry, R. G., and Gilichinsky, D.: Interdecadal changes in seasonal freeze and thaw depths in Russia, J. Geophys. Res., 109, D05101, doi:10.1029/2003JD004245, 2004.

Frolking, S., Roulet, N. T., Moore, T. R., Richard, P. J. H., Lavoie, M., and Muller, S. D.: Modeling northern peatland decomposition and peat accumulation, Ecosystems, 4, 479-498, 2001.

Gruber N., Friedlingstein, P., Field, C. B., Valentini, R., Heimann, M., Richey, J. E., Romero-Lankao, P., Schulze, D., and Chen, C.-T. A.: The vulnerability of the carbon cycle in the 21 st century: An assessment of carbon-climate human interactions, in: The Global Carbon Cycle: Integrating Humans, Climate, and the Natural World, edited by: Field, C. B. and Raupach, M. R., Washington DC, Island Press, 45-76, 2004. 
Hobbie, S. E., Schimel, J. P., Trumbore, S. E., and Randerson, J. R.: A mechanistic understanding of carbon storage and turnover in high-latitude soils, Glob. Change Biol., 6, 196-210, 2000.

Hollesen, J., Elberling, B., and Jansson, P. E.: Future active layer dynamics and carbon dioxide production from thawing permafrost layers in Northeast Greenland, Glob. Change Biol., 17, 911-926, doi:10.1111/j.1365-2486.2010.02256.x, 2011.

Isaksen, K., Sollid, J. L., Holmlund, P., and Harris, C.: Recent warming of mountain permafrost in Svalbard and Scandinavia, J. Geophys. Res.-Earth, 112, F02S04, doi:10.1029/2006JF000522, 2007.

Jones, C. D., Hughes, J. K., Bellouin, N., Hardiman, S. C., Jones, G. S., Knight, J., Liddicoat, S., O'Connor, F. M., Andres, R. J., Bell, C., Boo, K.-O., Bozzo, A., Butchart, N., Cadule, P., Corbin, K. D., Doutriaux-Boucher, M., Friedlingstein, P., Gornall, J., Gray, L., Halloran, P. R., Hurtt, G., Ingram, W. J., Lamarque, J.-F., Law, R. M., Meinshausen, M., Osprey, S., Palin, E. J., Parsons Chini, L., Raddatz, T., Sanderson, M. G., Sellar, A. A., Schurer, A., Valdes, P., Wood, N., Woodward, S., Yoshioka, M., and Zerroukat, M.: The HadGEM2-ES implementation of CMIP5 centennial simulations, Geosci. Model Dev., 4, 543-570, doi:10.5194/gmd-4-543-2011, 2011.

Khvorostyanov, D. V., Krinner, G., Ciais, P., Heimann, M., and Zimov, S. A.: Vulnerability of permafrost carbon to global warming. Part 1: Model description and role of heat generated by organic matter decomposition, Tellus B, 60, 265-275, doi:10.1111/j.1600-0889.2007.00333.x, 2008.

Koven, C. D., Ringeval, B., Friedlingstein, P., Ciais, P., Cadule, P., Khvorostyanov, D., Krinner, G., and Tarnocai, C.: Permafrost carbon-climate feedbacks accelerate global warming, P. Natl. Acad. Sci. USA, 108, 14769-14774, doi:10.1073/pnas.1103910108, 2011.

Kuhry, P., Dorrepaal, E., Hugelius, G., Schuur, E. A. G., and Tarnocai, C.: Potential remobilization of belowground permafrost carbon under future global warming, Permafrost Periglac., 21, 208-214, doi:10.1002/ppp.684, 2010.

Lawrence, D. M. and Slater, A. G.: A projection of severe nearsurface permafrost degradation during the 21 st century, Geophys. Res. Lett., 32, L24401, doi:10.1029/2005GL025080, 2005.

Lee, H., Schuur, E. A. G., Inglett, K. S., Lavoie, M., and Chanton, J. P.: The rate of permafrost carbon release under aerobic and anaerobic conditions and its potential effects on climate, Glob. Change Biol., 18, 515-527, doi:10.1111/j.13652486.2011.02519.x, 2012.

Lehner, B. and Döll, P.: Development and validation of a global database of lakes, reservoirs and wetlands, J. Hydrol., 296, 1-22, 2004.

Michaelson, G. J. and Ping, C. L.: Soil organic carbon and $\mathrm{CO}_{2}$ respiration at subzero temperature in soils of Arctic Alaska, J. Geophys. Res., 108, 8164, doi:10.1029/2001JD000920, 2003.

Murphy, J. M., Sexton, D. M. H., Barnett, D. N., Jones, G. S., Webb, M. J., Collins, M., and Stainforth, D. A.: Quantification of modelling uncertainties in a large ensemble of climate change simulations, Nature, 430, 768-772, 2004.

O’Connor F. M., Boucher, O., Gedney, N., Jones, C. D., Folberth, G. A., Coppell, R., Friedlingstein, P., Collins, W. J., Chappellaz, J., Ridley, J., and Johnson, C. E.: Possible role of wetlands, permafrost and methane hydrates in the methane cycle under future climate change: a review, Rev. Geophys., 48, RG4005,
doi:10.1029/2010RG000326, 2010.

Osterkamp, T. E.: Characteristics of the recent warming of permafrost in Alaska, J. Geophys. Res., 112, F02S02, doi:10.1029/2006JF000578, 2007.

Raupach, M. R. and Canadell, J. G.: Observing a vulnerable carbon cycle, in: The Continental-Scale, Greenhouse Gas Balance of Europe, edited by: Dolman, A. J., Valentini, R., and Freibauer A., Springer, New York, 5-32, 2008.

Schaefer, K., Zhang, T., Bruhwiler, L., and Bareett, A. P.: Amount and timing of permafrost carbon release in response to climate warming, Tellus B, 63, 165-180, doi:10.1111/j.16000889.2011.00527.x, 2011.

Schimel, J. P.: Plant transport and methane production as controls on methane flux from arctic wet meadow tundra, Biogeochemistry, 28, 183-200, 1995.

Schneider von Deimling, T., Meinshausen, M., Levermann, A., Huber, V., Frieler, K., Lawrence, D. M., and Brovkin, V.: Estimating the near-surface permafrost-carbon feedback on global warming, Biogeosciences, 9, 649-665, doi:10.5194/bg-9-649-2012, 2012.

Schuur, E. A. G., Bockheim, J.,. Canadell, J. G, Euskirchen, E., Field, C. B., Goryachkin, S. V., Hagemann, S., Kuhry, P., Lafleur, P. M., Lee, H., Mazhitova, F.E. Nelson, A. Rinke, V.E. Romanovsky, N. Shiklomanov, C. Tarnocai, G., Venevsky, S., Vogel, J. G., and Zimov, S. A.: Vulnerability of permafrost carbon to climate change: implications for the global carbon cycle, Bioscience, 58, 701-714, doi:10.1641/B580807, 2008.

Schuur, E. A. G., Vogel, J. G., Crummer, K. G., Lee, H., Sickman, J. O., and Osterkamp, T. E.: The effect of permafrost thaw on old carbon release and net carbon exchange from tundra, Nature, 459, 556-559, 2009.

Shakhova, N., Semiletov, I., Salyuk, A., Yusupov, V., Kosmach, D., and Gustafsson, Ö.: Extensive Methane Venting to the Atmosphere from Sediments of the East Siberian Arctic Shelf, Science, 327, 1246-1250, doi:10.1126/science.1182221, 2010.

Shea, K.: Quantifying diffusion, ebullition, and plant-mediated transport of $\mathrm{CH}_{4}$ in Alaskan peatlands undergoing permafrost thaw, University of Guelph, 93 pp., MR71490, 2011.

Shiklomanov, N. I., Streletskiy, D. A., Nelson, F. E., Hollister, R. D., Romanovsky, V. E., Tweedie, C. E., Bockheim, J. G., and Brown, J.: Decadal variations of active-layer thickness in moisturecontrolled landscapes, Barrow, Alaska, J. Geophys. Res., 115, G00I04, doi:10.1029/2009JG001248, 2010.

Solomon, S., Qin, D., Manning, M., Chen, Z., Marquis, M., Averyt, K. B., Tignor, M., and Mill, H. L. (Eds.): Climate Change 2007: The Physical Science Basis, Cambridge University Press, Cambridge, United Kingdom and New York, NY, USA, 2007.

Tarnocai, C., Canadell, J. G., Schuur, E. A. G., Kuhry, P., Mazhitova, G., and Zimov, S.: Soil organic carbon pools in the northern circumpolar permafrost region, Global Biogeochem. Cy., 23, GB2023, doi:10.1029/2008GB003327, 2009.

Turetsky, M. R., Wieder R. K., and Vitt, D. H.: Boreal peatland C fluxes under varying permafrost regimes, Soil Biol. Biochem., 34, 907-912, 2002.

Uhlirová, E., Šantrucková, H., and Davidov, S. P.: Quality and potential biodegradability of soil organic matter preserved in of Siberian tussock tundra, Soil Biol. Biochem., 39, 1978-1989, 2007.

Waldrop, M. P., Wickland, K. P., White III, R., Berhe, A. A., Harden, J. W., and Romanoovsky, V. E.: Molecular investiga- 
tions into a globally important carbon pool: permafrost-protected carbon in Alaskan soils, Glob. Change Biol., 16, 2543-2554, doi:10.1111/j.1365-2486.2009.02141.x, 2010.

Walter, K. M., Zimov, S. A., Chanton, J. P., Verbyla, D., and Chapin III, F. S.: Methane bubbling from Siberian thaw lakes as a positive feedback to climate warming, Nature, 443, 71-75, 2006.

$\mathrm{Wu}, \mathrm{Q}$. and Zhang, T.: Changes in active layer thickness over the Qinghai-Tibetan Plateau from 1995 to 2007, J. Geophys. Res., 115, D09107, doi:10.1029/2009JD012974, 2010.

Zhang, T., Barry, R. G., Knowles, K., Heginbottom, J. A., and Brown, J.: Statistics and characteristics of permafrost and ground-ice distribution in the Northern Hemisphere, Polar Geography, 23, 132-154, 1999.

Zhang, T., Barry, R. G., Knowles, K., Ling, F., and Armstrong, R. L.: Distribution of seasonally and perennially frozen ground in the Northern Hemisphere, in: Permafrost, edited by: Phillips, M., Springman, S. M., and Arenson, L. U., Swets \& Zeitlinger, Lisse, 1289-1294, 2003.
Zhuang, Q., Melillo, J. M., Kicklighter, D. W., Prinn, R. G., McGuire, A. D., Steudler, P. A., Felzer, B. S., and Hu, S.: Methane fluxes between terrestrial ecosystems and the atmosphere at northern high latitudes during the past century: A retrospective analysis with a process-based biogeochemistry model, Global Biogeochem. Cy., 18, GB3010, doi:10.1029/2004GB002239, 2004.

Zhuang, Q., Melillo, J. M., Sarofim, M. C., Kicklighter, D. W., McGuire, A. D., Felzer, B. S., Sokolov, A., Prinn, R. G., Steudler, P. A., and $\mathrm{Hu}$, S.: $\mathrm{CO}_{2}$ and $\mathrm{CH}_{4}$ exchanges between land ecosystems and the atmosphere in northern high latitudes over the 21 st century, Geophys. Res. Lett., 33, L17403, doi:10.1029/2006GL026972, 2006. 